\title{
Separated but Whole: Pursuing Health and Redefining Community amidst COVID-19
}

\section{Jordan Millhollin}

${ }^{a}$ BS, Theology, Medicine, and Culture Fellow at Duke Divinity, Durham, NC, USA

\begin{abstract}
In his speech "Health is Wholeness," Wendell Berry says that when we are healthy, we are unconscious of our bodies-only sickness brings our attention to them. He also says that people's sense of wholeness is tied to community, and any removal from common life together is a denial of wholeness and a removal of health. As we find ourselves in this strange COVID-19 moment, we are wrestling with a sudden awareness and anxiety about our own bodies while also hearing the call for social separation that takes us apart from the communities which provide us meaning. This is precisely the type of issue that Berry describes; a closer look at Berry's theological leanings may give us the resources we need to find hope and meaning during this crisis. Within COVID-19's clear violation of wholeness, Berry's understanding of health as interconnection and orientation toward one another under God's divine love is a faithful and loving way to find meaning during this crisis. If we follow Berry's assertion that under Christ the community is the smallest unit of health, then observing social distancing for the sake of public health is faithfully in line with a theological vision of health as wholeness.
\end{abstract}

Key Words: Wendell Berry, COVID-19, coronavirus, Christian life, health, wholeness.

In his speech "Health is Wholeness," Wendell Berry says that when we are healthy, we are unconscious of our bodies - only sickness brings our attention to them. He also says that people's sense of wholeness is tied to community, and any removal from common life together is a denial of wholeness and a removal of health. As we find ourselves in this strange COVID-19 moment, we are wrestling with a sudden awareness and anxiety about our own bodies while also hearing the call for social separation that takes us apart from the communities which provide us meaning. This is precisely the type of issue that Berry describes; a closer look at Berry's theological leanings may give us the resources we need to find hope and meaning during this crisis. Within COVID-19's clear violation of wholeness, Berry's understanding of health as interconnection and orientation toward one another under God's divine love is a faithful and loving way to find meaning during this crisis. If we follow Berry's assertion that under Christ the community is the smallest unit of health, then observing social distancing for the sake of public health is faithfully in line with a theological vision of health as wholeness.

In the past few weeks, most of us have gone from a blissful unawareness of our bodies to constantly thinking about washing our hands and not touching our faces, as well as gauging the distance we keep from those around us. However, while physically distancing ourselves is necessary to stop the spread of the virus which causes COVID-19, such physical division from one another has made us acutely aware of how we need each other and the social systems we inhabit to bring meaning to our lives. Without gathering for church, school, or work, we know that there is something off about the world. We no longer feel whole. We no longer feel healthy.

According to agrarian essayist and Christian 
thinker Wendell Berry, to be healthy is to be whole. ${ }^{1}$ For the most part, our sense of wholeness is difficult to recognize because when our bodies are healthy, nothing readily draws our attention to them - we are unaware of our wholeness. It takes pain, fear, or disease to make us conscious of our bodies, and then we can pay attention to little else. For instance, when we have a stomachache, we can barely think of anything else.

Similarly, our sense of health as wholeness is also tied to an unconscious need to belong to a community. If together and sharing life in common with one another is an expression of human wholeness, then imagining ourselves as isolated beings is a division of wholeness and a violation of health.

This view of what Berry labels as "Health is Membership" certainly describes our life during the current pandemic.

How might we find health and wholeness in an age when living under the threat of death has violated the unconscious wholeness of our bodies? Perhaps even more obviously for our daily lives, what might health look like in a time when physical distancing is vital to "flattening the curve?"2 In Berry's words, how might we find wholeness in a world in which, "disintegration and division, isolation and suffering seem to have overwhelmed us?"3

Given COVID-19's clear violation of wholeness, Berry's understanding of health still gives us the resources to faithfully imagine what it means to be healthy and whole, even during a time of anxious bodily awareness and the need for physical distancing.

First, it is important to indicate how Berry's account of health is different from the medicalized definition, which tends to see the body as a machine made up of isolated and occasionally failing components. For example, Berry claims, "the human heart ... is no longer understood as the center of our emotional life or even as an organ that pumps; it is understood as "a pump," having somewhat the same function as a fuel pump in an automobile." ${ }^{4}$ When the pump is broken, it can be fixed with "mechanical tinkering" that does not need to acknowledge the habits, narrative, or commitments of the patient. If there is ever an instance in which the pump cannot be fixed, the patient is doomed never to be considered "healthy" again.

However, such an account of health misidentifies our nature. Bodies cannot be machines because without fuel a machine is still a machine, but without "air, food, drink, clothing, shelter, and companionship," a body is not a body but a cadaver. ${ }^{5}$ Our bodies cannot be machines because they are not self-contained; rather, they extend outward through how we interact with the world and others around us. Our mind even more obviously exceeds itself, as our contribution to culture and relationships cannot be pinpointed to a physical location within our body.

Because our bodies exceed themselves, wholeness is not something that mere individuals can possess. Our reliance on and interconnection with others makes "a place and all its creatures ... the smallest unit of health and ... to speak of the health of an isolated individual is a contradiction in terms." ${ }^{\prime 6}$

Of course, focusing on one part does not always necessarily happen at the exclusion of the whole. For instance, when a cardiologist places a stent, it is good that they focus on the heart to prevent myocardial death and resulting death of the entire body. When a family physician pays attention to examining the body of the patient in front of them, they are not elevating that patient's particular body over bodies of the patients in the waiting room or those outside the clinic. In fact, compassionate and undivided attention toward to the patient's body in that moment is a caring affirmation that the patient is made in God's image. Violating wholeness does not come when attending to, particularity if it is proper to do so, but in doing so when it comes at the expense of others.

An account of health that focuses on components of the body by ignoring others or emphasizes the value of certain individuals within a larger community doesn't properly understand the embodied and interconnected nature of humanity — something that Saint Paul underscores in his presentation of the Church as one Body in 1 Corinthians 12:12-27. Like Berry, Paul recognizes our fundamental interconnectedness, for "[i]f one member suffers, all suffer together with it; if one member is honored, all rejoice together with it."

Each of us is held together to one another not just by our own effort, but by the sustaining love that Christ has for us as interconnected people. All things are held together by love (Colossians 3:14).

God's love does not pass over the sparrows (Matthew 6:26), the one lost sheep (Matthew 18:1214, Luke 15:3-7), or the poor (Luke 1:53-53). God is attentive, paradoxically, to all, as they form a whole, 
but also to each, in his or her particularity. Thus, when we learn that a new therapy or medication will save most of those who are sick, we are called to remember the global marginalized "least of these" who may otherwise be denied treatment. Recognizing that each person is irreplaceable and valued within the health of the community, the world of love cannot accept marginalization of the elderly or any other life..$^{7-8}$

In the age of the COVID-19 pandemic, we cannot afford to think of ourselves as isolated individuals even if we are being told to self-isolate. Yes, it is abundantly clear from epidemiological estimates that reducing the impact of COVID-19 depends on our ability to remain physically distant from one another, but we do so for the greater health of all - something we also see when we as individuals are inoculated for, say, measles, as the immunity of each of us contributes to the immunity of the "herd."

In that respect, we are profoundly interconnected, even as we are called to be apart. During this pandemic, we cannot rightly think of our health as our ability to survive as individuals. Knowing that we rely on one another for health and wholeness, we cannot afford to selfishly or fearfully hoard resources like hand sanitizer, toilet paper, or N95 masks. ${ }^{10-12}$ Similarly, even if someone does not fall within the "atrisk" category, acting with love for the wholeness and health of the community requires that they follow the $\mathrm{CDC}$ and WHO recommendations to remain at home. If Berry's account of health and the world of love is to be taken seriously, any loss of life within our global community would be a tragic loss to the communal body.

Unfortunately, tragedy like this is bound to happen. We have already seen hundreds of thousands of lives lost due to the pandemic, and it is projected that we will continue down this path. How might we still have hope? What will keep us moving forward?

A turn to Berry reminds us that the world of divine love that sustains and interconnects us is not blind to tragedy or death. We can be assured through Jesus as the incarnate and embodied God that divine love recognizes the brokenness of this world, yet still chooses to involve itself "inescapably in the limits, sufferings, and sorrows of mortality." 13

Jesus does not turn his face away from suffering and death but leans into it alongside us. Even now, in the face of COVID-19, “ . . . the threat of death, and death itself, [love] insists unabashedly on its own presence, understanding by its persistence through defeat that it is superior to whatever happens." 14

The question for those of us living in the COVID-19 moment, then, is how we might better love each other despite the ongoing crisis. Love looks like the frontline medical response where nurses, and doctors, and others refuse to ignore the needs of the sick despite personal risk. Love looks like adhering to physical distancing guidelines while still checking in on those around us as an affirmation that their lives matter deeply.

Love in accordance with Jesus's teaching and a vision of shared wholeness also requires ongoing witness and action, even in the months after physical distancing ends. Side effects of mitigating the COVID-19 spread will spill into the global economy, and those who already live in impoverished communities around the world will be significantly afflicted. ${ }^{15}$ Recognizing this, love for global wholeness will not accept the marginalization of any individual or elevation of one community over another, because doing so directly damages our shared health. As we think about faithfully working for global health in the months to come, we must think in terms of moving toward wholeness and acting out of love to ensure that the entire global body is cared for.

By continuing to love one another and advocating for wholeness even in the midst of physical separation, we serve as reminders to one another that despite worldly brokenness, bodily fear, and societal anxiety, we recognize a greater Light that "shines in the darkness, and the darkness did not overcome it" (John 1:5).

\section{References}

1. Berry W. Health is membership [Internet]. Presented at the Conference on Spirituality and Healing, Louisville, KY; 1994 Oct 17. Available from: https://scienceandsociety.duke.edu/wordpress/wpcontent/uploads/Berry-Health-is-Membership.pdf.

2. Fineberg HV. Ten weeks to crush the curve. $\mathrm{N}$ Engl J Med [Internet]. 2020 Apr 1 [cited 2020 Apr 13]. https://www.nejm.org/doi/full/10.1056/NEJMe20072 $\underline{63 .}$

3. Berry W. Health is membership. 1.

4. Berry W. Health is membership. 4.

5. Berry W. Health is membership. 4.

6. Berry W. Health is membership. 2.

7. Aronson L. 'Covid-19 kills only old people.' Only? [Internet]. The New York Times Opinion. 2020 Mar 
22 [cited 2020 Apr 13]. Available from:

https://www.nytimes.com/2020/03/22/opinion/corona virus-elderly.html.

8. Moore R. God doesn't want us to sacrifice the old [Internet]. The New York Times Opinion [Internet]. 2020 Mar 26 [cited 2020 Apr 14]. Available from: https://www.nytimes.com/2020/03/26/opinion/corona virus-elderly-vulnerable-religion.html?smid=fb-share

9. Ferguson NM, Laydon D, Nedjati-Gilani G, Imai N, Ainslie K, Baguelin M, et al. Impact of nonpharmaceutical interventions (NPIs) to reduce COVID-19 mortality and healthcare demand. Imperial College COVID-19 Response Team. 2020 March 16 [cited 2020 Apr 13]. Available from: https://www.imperial.ac.uk/media/imperialcollege/medicine/sph/ide/gida-fellowships/ImperialCollege-COVID19-NPI-modelling-16-03-2020.pdf.

10. Nicas J. He has 17,700 bottles of hand sanitizer and nowhere to sell them [Internet]. The New York Times. 2020 Mar 14 [cited 2020 Apr 13]. Available from:

https://www.nytimes.com/2020/03/14/technology/cor onavirus-purell-wipes-amazon-sellers.html.

11. Kavilanz P. Toilet paper makers: 'what we are dealing with here is uncharted' [Internet]. CNN Business. 2020 Mar 19 [cited 2020 Apr 13]. Available from:

https://www.cnn.com/2020/03/17/business/toiletpaper-supply-chain-coronavirus/index.html

12. Thorbecke C. Americans hoarding hand sanitizer, face masks and oat milk amid coronavirus fears [Internet]. ABC News. 2020 Mar 4 [cited 2020 Apr 13]. Available from:

https://abcnews.go.com/Business/americanshoarding-hand-sanitizer-face-masksamid $\% 20$ coronavirus/story $\mathrm{id}=69385946$

13. Berry W. Health is membership. 8.

14. Berry W. Health is membership. 8.

15. Grills N. COVID-19: containment, poverty and population health [Internet]. 2020 Mar 23 [cited 2020 April 13]. In: AMA InSight+. Available from: https://insightplus.mja.com.au/2020/11/covid-19containment-poverty-and-population-health/

Competing Interests: None declared.

Correspondence: Jordan Millhollin, Durham, NC, USA. jordan.millhollin@gmail.com

Cite this article as: Millhollin J. Separated but whole: Pursuing health and redefining community amidst COVID-19. Christian Journal for Global Health. April 2020; 7(1):20-23. https://doi.org/10.15566/cjgh.v7i1.367

(C) Authors. This is an open-access article distributed under the terms of the Creative Commons Attribution License, which permits unrestricted use, distribution, and reproduction in any medium, provided the original author and source are properly cited. To view a copy of the license, visit http://creativecommons.org/licenses/by/4.0/ 